\title{
Prophetic Witness AND PUblic Discourse in EUROPEAN SOCIETIES - A GERMAN PERSPECTIVE
}

Author:

Heinrich Bedford-Strohm ${ }^{1,2}$

\author{
Affiliations: \\ ${ }^{1}$ Otto-Friedrich \\ University Bamberg, \\ Germany
}

${ }^{2}$ Systematic Theology and Ecclesiology, University of Stellenbosch, South Africa

\section{Correspondence to:}

Heinrich Bedford-Strohm

email:

heinrich.bedford-strohm@ uni-bamberg.de

Postal address:

Universität Bamberg,

Markusplatz 3, D-96045

Bamberg, Germany

\section{Keywords:}

Public Theology; public discourse; civil society; prophetic witness; option for the poor; economic ethic

\section{Dates:}

Received: 15 Jan. 2010

Accepted: 14 Apr. 2010

Published: 08 Oct. 2010

How to cite this article: Bedford-Strohm, H. 2010, 'Prophetic witness and public discourse in European societies - a German perspective', HTS Teologiese Studies/ Theological Studies 66(1), Art. \#784, 6 pages. DOI: 10.4102/hts.v66i1.784

\section{This article is available} at: http://www.hts.org.za

\section{Note:}

This article was initially presented as a paper at the conference on 'Prophetic witness: An appropriate mode of public discourse in democratic societies?' that was held at the University of Pretoria on 26-27 October 2009.

Dr Bedford-Strohm is a research associate of Prof. Etienne de Villiers, at the University of Pretoria, South Africa.

(C) 2010. The Authors. Licensee: OpenJournals Publishing. This work is licensed under the Creative Commons Attribution License.

\section{ABSTRACT}

The role of prophetic witness of the churches in the public discourse of modern civil societies is analysed on the basis of three public memorandums of the German Protestant churches on economic questions and their impact on the public. Among the ten systematic conclusions which are drawn from this case study is the importance of the specific context for the role of prophetic statements. The article tries to show how prophetic witness is a necessary element of a public theology, which is not based on fundamental criticism, but develops both critical and constructive perspectives for politics and society. If such public theology is liberation theology for a democratic society it is the task of the church to get involved in the public debate in a 'bilingual' way, that is, on the basis of its biblical-theological sources but at the same time with the ability to engage in the secular language of pluralistic societies.

\section{INTRODUCTION}

\section{The power of prophetic speech}

One of the most troubling but also impressive stories of the Bible is the so called 'Nathan Parable' (2 Sm 12). It is the story of a prophetic witness. After King David's misuse of power to support his affair with Bathsheba, God sends the prophet Nathan to see David. The prophet tells the king the story of the rich man who has many sheep and the poor man who has only one sheep which he holds 'like a daughter'. When the rich man has a visitor, he wants to prepare a sheep to eat with him. And since he cannot get himself to give up any of his own sheep he goes to the poor man, takes his sheep and prepares it for the visitor. When the king hears this, he gets very angry and says: 'As the LORD lives, the man who has done this deserves to die' and Nathan says to David: 'You are the man!'

The most challenging and thought-provoking aspect of this story is not the substantial critique of David's behaviour; it is not even the courage of the prophet confronting the most powerful man of his time. The most challenging aspect is the moral outrage of the king. David is honestly angry and upset about the clearly unacceptable behavior of the rich man. And he does not even notice the analogy to his own behavior. It does not come to his mind that his power abuse in his desire for Bathsheba is of the exact same quality as the rich man's abuse of power against the poor man.

It is challenging for us today because it directs our attention to those injustices that are so much part of our daily behavior that we do not even notice. It makes us aware of the fact that with every finger we point toward another person, four fingers point back to us. It reminds us of our tendency to look at the speck in our neighbour's eye, but not notice the log in our own eye.

It is obvious that this has manifest consequences for political life. It is no coincidence that it is a king who is addressed in the story. It is certainly also a story about two individuals, but behind that, it is definitely a story about the relationship between church and state raising urgent questions for today: how can the churches critically accompany the political process? Should they speak up to power in ways which are more shocking than comforting and sustaining? Or should they cultivate a relationship to government and its officials which is characterised by solidarity and support?

When I speak about this question as a European, I am very aware of the contextual dimension. Firstly, I speak from a context which is in most cases characterised by a history of close partnership between church and state. In Germany, there is a separation of church and state, but to this day, most of those who share political responsibility consider themselves Christians and that means as members of their church. In most cases this self identification has to be considered sincere.

Secondly, I speak from the context of one of the most powerful economies in the world. I speak from the context of a country which, despite the existence of winners and losers in this context as well, has as a whole greatly profited from the processes of globalisation. I speak from the context of the affluent world and, as an university professor, from the context of the more wealthy segment of society in the affluent world. Everybody will agree that this is of considerable significance. If the poor and starving Lazarus in the famous gospel story (Lk 16:19-31) accuses the rich man of not sharing his wealth with the poor, an answer faithful to the gospel could certainly not be: 'Why do you see the speck in your neighbour's eye, but do not notice the log in your own eye?' The same biblical sentence which is highly impressive in the right context can become cynical in the wrong context. The context matters (Boesak 2009:62-63).

\section{THE VOICE OF THE CHURCH IN PUBLIC DISCOURSE}

\section{Three case studies from the German context}

The public voice of the church in Germany

Being aware of this context, I want to give an insight into some of the discussions made on several highly significant public statements by the Protestant churches in Germany on the economy, which reflects 
the complicated relationship between prophetic witness and prophetic speech. I will look at three documents. The first one is a memorandum on overcoming poverty issued by the Council of the Evangelische Kirche in Deutschland (EKD) in July 2006 (Council of the EKD 2006). The second one is a memorandum on business ethics from a protestant perspective published in July 2008, which sparked a heated debate (Rat der EKD 2008), and the third one is a widely recognised public statement by the Council of the $E K D$ in reaction to the economic and financial crisis in July 2009 (Council of the EKD 2009).

All three of these are different responses to our question of prophetic witness and public discourse. The first two statements were written by the EKD Advisory Chamber of Social Order in which numerous representatives of public life are represented, appointed by the Council of the EKD. The secretary of the German employers association is as much a member of this chamber as the then vice-president of the German association of labour unions, but also several members of parliament, a former cabinet minister, professors of economy and of course some theologians. What connects them all is their sincere aspiration to live as Christians in their daily lives and in their professional existence. Yet the differences in profile of the persons mentioned and their plural backgrounds make it difficult to issue clear prophetic statements. Such documents are the result of a long process in which a small redactionary group goes back and forth into the chamber with different versions of the coming statement. If the Council of the EKD thinks that the statement has the necessary quality and that it represents the views of the Council, it is then published as a 'Denkschrift' which means, literally translated, a 'thinking document', because it wants to initiate or support a thinking process among Christians. If the Council remains unsatisfied it can also end up in the waste paper basket.

The third of the three statements has a slightly different history of origin. It was written by a small group of people from church administration, from the EKD council itself and only two people from the chamber. Maybe this different history is part of the reason why this document is - as I will argue - the most prophetic one.

\section{Just participation: Empowerment for personal responsibility - the poverty memorandum}

I will only briefly present the first document. It was written in the context of a growing gap between rich and poor in Germany due to continuingly high numbers of unemployment (around 10 per cent). Due to the shift of untrained jobs to countries with labour cheaper than in Germany, more and more people among those with a low level of education were in danger of losing their jobs indefinitely. The statement elaborated on the preferential option for the poor and interpreted it as a call to just participation for each member of society. It made a plea for 'enabling justice' as complementary to distributive justice, which meant a call to massively invest in education and various forms of empowerment especially for those who did not have equal chances due to a long time poverty background of their families. The emphasis, thus, lay on empowerment to take responsibility oneself, but the statement made very clear that the basis of such self-reliance was the solidarity of society to enable every person to take personal responsibility.

The last chapter challenges congregations to face their exclusive existence as communities for the educated middle class rather than being inclusive communities and living examples for just participation. It calls for new initiatives to include the poor in the parishes. The document affirms:

Individual Christians, as well as the church and diaconal institutions, are especially challenged in regard to fighting poverty. The acceptance of involuntary poverty in society represents a societal and individual failure before the claims and commandments of God. Our society enjoys access to a greater wealth of resources than ever before in the history of humankind.
Therefore we have no excuse - we must be resolute in seeking to overcome poverty and the lack of participation in society. A church that does not demand justice, whose members know no compassion and do not open their hearts to the poor - or even go as far as to deprive them of opportunities to participate in society - such a church, despite any external success or social recognition, is not the Church of Jesus Christ.

\section{(Council of the EKD 2006:5-6)}

If one takes into account that these sentences were not only supported by theologians but also by political representatives and professional bankers, all members of the Council of the EKD, this statement was a remarkable input into the public debate and maybe something like a 'representative new consensus' for society as a whole, found by the church on the basis of the gospel. It did indeed generate and foster an intensified debate in the German public on poverty and its overcoming. It represents prophetic elements but also analyses the situation very carefully and makes concrete political proposals which had a chance to find consensus also among those who bear political responsibility. A program for 100000 jobs for unskilled unemployed people financed by the government followed soon after the publication of the document and there are reasons to believe that the churches' public voice was one of its midwives. While the poverty memorandum was widely praised across political parties and societal milieus, the second statement I want to refer to generated a heated debate, especially within the church (for the most recent and comprehensive account see Reihs 2009).

Entrepreneurial activity in Protestant perspective - the business ethics memorandum

For a long time, the relationship between people working in business (especially owners of companies, Chief Executive Officers (CEOs), as well as small business people) and the Protestant church was characterised by tension. The aspiration to make a profit from business seemed to be in conflict with the biblical commandment to serve your neighbour without expecting revenue. People whose daily job it was to generate revenue did not feel welcome in the parishes, or even felt excluded. They perceived the Protestant church as a community which was politically biased to the political left and which did not take into account the concerns of entrepreneurs and business people.

In this situation, the Council of the EKD decided to put the relationship with the business world on a new footing and asked the chamber to work out a document on the ethics of entrepreneurial activity, which could be a basis for a new dialogue between church and business. In a way, one can say that one of the leading intentions was pastoral rather than prophetic: by saying yes to their daily professional existence, business people were to be drawn into a dialogue on the ethics of their professional activities. The yes was not a general approval for their activities but a 'conditional yes'. On the one hand, the document, which was then worked out by the chamber, indeed recognised entrepreneurial activity as an activity that potentially serves the community by generating wealth. On the other hand, it gave clear guidelines for making a judgment as to whether it really served the community or whether it only served the greed of some to maximise their profits. The background idea was a social market economy which sees the market and private entrepreneurial activity as a vital source of wealth, but demands a legal framework which makes sure that the fruits of such wealth are widely distributed so that each member of society profits from it.

Its basic theological point was a new understanding of freedom as 'communicative freedom', which means that freedom is never the freedom of the individual only, but always includes service to others, as Martin Luther explained it in his famous treatise 'On Christian Liberty' in 1520 (Luther 2003). From that, the statement came to the conclusion that the dignity of the human being must always be the basic criterion for entrepreneurial activity, 
meaning that human beings can never be purely means to an end but must always be an end in itself, as Kant's (1911:43) famous formulation states. Also invoking the United Nations (UN) pact of 1966 on social human rights, it affirms that employees may never be purely instrumentalised. The document then continues:

When employees are disregarded in their fundamental human needs, when their dignity is thus ignored, they are reduced to being purely means toward an end. Such a reduction to being means towards an end happens when lay-offs are not only used as a very last resort, but as a way to further increase already high profits. It happens when companies employ people in emerging markets for starvation wages and let them work under conditions which endanger their life or their health, or when children have to work without a chance of education. It happens when employees in our country don't dare to stay at home when they are sick or to go to the doctor or when there is a climate in the company in which all human communication is strictly subordinated to the economic interest of the company, and the social fabric plays no role anymore.

(Rat der EKD 2008:43)

The document affirms a social market economy approach in which free enterprise is framed by government regulation that institutionalises its social responsibility. Briefly before the outbreak of the global financial crisis, it calls for 'well regulated capital markets' (Thesis 6:77), implying the necessity of new regulation (for which concrete proposals are made), but also avoiding a fundamental condemnation of capital markets.

Such social market economy is seen as a model potentially helpful for a humanisation of globalisation:

The concept of social market economy catches increasing interest in more and more countries worldwide, especially in those emerging markets which profit economically most from globalization. Especially these countries recognize that the onesided emphasis on a rapid economic growth can lead to grave internal disruptures in their societies and endangers their social cohesion. They note an enormous backlog demand in the social realm. It is especially Germany from which effective help and even concrete advice is expected. Thus the model of social market economy could prove to be a model to strengthen the social dimension of globalization. It also remains the guiding principle for entrepreneurial activity and the decisions connected with it. It should lead to the reorientation of global competition on labour markets and production sites along the criteria of fairness, justice and humaneness.

(Rat der EKD 2008:57)

If one takes into account the strong emphasis on social responsibility which these passages show, one might be surprised that the reaction among some of the socially engaged Christians in Germany was very critical. Those who expected a fundamental criticism of capitalism instead of a call to responsibility to entrepreneurs, which of course implied the acceptance of markets as an instrument for generating wealth were disappointed, some even shocked. They understood the document as a document promoting neoliberalism and saw it in fundamental opposition to the ecumenical process of confession expressed in the Accra document. A group of critics led by German theologian Ulrich Duchrow published a book against the statement (Duchrow \& Segbers 2008) and initiated a signature campaign calling for the 'revocation' of the document by the $E K D$. They collected about 1100 signatures in the year following the publication of the document.

One can very well interpret this reaction as the expression of a deep dismay about a perceived lack of prophetism in the public voice of the church. Instead of fundamentally criticising the system they thought the document accepted the existing framework of our economy too much and thereby betrayed the fundamentally critical impulse of the gospel.

The question behind the conflict is a fundamental question about the place of prophetic speech in public discourse: is it a special sign of faithfulness to the gospel if the public voice of the church is characterised by a condemnation of the existing system, which would include the daily activities of those who have responsibility in this system? Or is the more faithful way a call to their conscience to act along specific ethical criteria in their daily activities while at the same time engaging in a debate about the best ways to improve the political design of the economy in favour of the poor? Or do both approaches have to be related to each other?

It has to be noted that, very differently from the openly visible, daily dehumanisation of human beings in the apartheid system in South Africa, people of good will can come to different conclusions about the reasons for dehumanisation through poverty and marginalisation and the best economic strategies to foster human dignity. Other than a fundamental critical approach, which binds the option for the poor exclusively to one political option, a public theological approach, which I myself advocate, generates an open discourse in which political options best serve the ethical goals (Bedford-Strohm 2008). In this perspective, prophetic witness can only be an appropriate mode of public discourse in societies when it does not block, but generates and encourages, such debate.

This aim was maybe best fulfilled by the third public statement I want to speak about.

'Like a high wall, cracked and bulging'; the statement by the Council of the Evangelical Church in Germany on the global financial and economic crisis

As already mentioned, this statement was written by a small group of people called together by the Council of the EKD. After the council had intensively discussed the economic crisis, it came to the conclusion that the church had to say a clear word which would help prevent government policies from simply continuing as before once the worst of the crisis was over. Already in the first meeting of the group, the decision was made that it was supposed to be a prophetic word which would set the tone for the document and even form its title. Prophetic witness in this case seemed to be the right mode of contribution to public discourse, because its intention was a change of minds and hearts in a specific kairos in history. The appropriateness of prophetic speech in this case relied on two factors. Firstly, the public was especially open to new ideas in a situation in which many of the old ideas about unregulated markets and miraculous growth had proved to be wrong. Secondly (and I think this is especially important), it could build on a high amount of trust and credibility among the acting parties which the former statements on the economy had generated. This prophetic voice was taken seriously, because it came from an institution which had been shown not to talk over the heads of those engaged in the daily political process, but had given concrete ethical orientation also for those in power. The voice of the powerless expressed in prophetic speech needs to be grounded in relationship, which includes those who are in power, at least if they sincerely try to be Christians. The prophet Nathan could only speak to King David and David only listened because they were in a relationship.

The statement began with a reflection on a passage in Isaiah which also gave the document the title. Let me first quote the passage in Isaiah as it is quoted in the statement:

Go now, write it before them on a tablet, and inscribe it in a book, so that it may be for the time to come as a witness forever. For they are a rebellious people, faithless children, children who will not hear the instruction of the Lord: who say to the seers: 'Do not see' and to the prophets: 'Do not prophesy to us what is right; speak to us smooth things, prophesy illusions, leave the way, turn aside from the path, let us hear no more about the Holy One of Israel.' Therefore says the Holy One of Israel: Because you reject this word, and put your trust in oppression and deceit, and rely on them: therefore this iniquity shall become for you like a break in a high wall, bulging out, and about to collapse, whose crash comes suddenly, in an instant;(...) For thus said the Lord God, the Holy One of Israel: In returning and rest you shall be saved; in quietness and trust shall be your strength. But you refused ...

(Is 30:8-15) 
The following reflection of the document on this prophetic word emphasises its call to not remain on the wrong course.

Anyone who hears prophetic words like that will sense how relevant they are to the present time. After all, among Christians throughout the world and in Germany, there have long been voices pressing for sweeping changes in the financial markets and economic policy. Instead, people preferred to hear pleasant, reassuring messages.

(Council of EKD 2009:8)

The document then explains its understanding of political intervention by the church:

If the churches now intervene in politics, it is not in order to take political action, but to enable it. Even if, in such a crisis, no one can foresee the impact of their own thinking and action, it is still necessary to make the most urgent decisions in good conscience and to do all that is humanly possible to ensure that the next generations have life and a future. No more is demanded of us, but also no less. The future lies in God's hand. On that we rely.

(Council of EKD 2009:8)

The essence of the passage is that the church is not the better political judge and should therefore not be a political force itself. But with its spiritual and ethical authority it can call politics to renew its commitment to ethical orientations as a basis for political judgment.

The President of the Council of the EKD Bishop Wolfgang Huber, further explained the choice of the prophetic word in his preface and linked it with the challenge of climate change:

Two years ago it [the chosen biblical passage, HBS] inspired our appeal on climate change (...). We have again taken up this Old Testament passage, since the shock-waves from the financial and economic crisis cannot be separated from the challenges of climate change. They both call for a complete change in thinking and acting, going beyond short-time crisis management. The turnaround must become a change of heart. The prophetic instruction gives us guidance...

(Preface by W. Huber, Council of EKD 2009:3)

Huber further explains the prophetic image and relates it to the idea of a social market economy:

A social and sustainable market economy relies on firm moral foundations. To use the image from Isaiah, there must be an ethical foundation supporting the wall, and the mortar of trust to hold the bricks together. The essential foundation of the social market economy is responsible freedom. The present crisis clearly shows that only responsible freedom is true freedom. That applies as much to business and politics as it does to personal behavior. Freedom without responsibility disintegrates. When people are not mindful of the consequences of their actions, the common good suffers. When they are not attentive to others, there is a breakdown of structures to rely on. The EKD Council seeks to strengthen trust and responsibility and express encouragement for a future in freedom and justice. We call for a change of heart-late, but hopefully not too late.

(Preface by W. Huber, EKD 2009:4)

In its analysis of the situation, the document refers to four levels of ethical reflection, (1) the level of individual responsibility (e.g. the consumer, but also the CEO as an individual), (2) the level of the companies and institutions (e.g. the relationship between maximisation of profits as goal and the dignity of employees or ecological responsibilities), (3) the level of the political-structural framework of the economy (e.g. laws and regulations) and (4) the level of the socio-cultural norms which drive our behavior (e.g. money as opposed to solidarity as the highest goal).

Several levels come together in a passage which relates this statement explicitly to the business ethics memorandum in a conscious effort to emphasise that the two statements cannot be put against each other:
The economy exists for the sake of people, not for its own sake. Where money is at the center, doing business becomes inhuman. In the future there will be a need both for robust regulation of the world financial markets and effective rules to make decision-makers liable for their actions. Freedom decoupled from responsibility ends up destroying itself. In the memorandum on entrepreneurial action from a Protestant perspective, which we published in 2008 before the financial crisis, we emphasize: Through globalization 'there has been a growth in the political responsibility to stipulate conditions for industry and business and to check on compliance - a responsibility to which national policy-makers must do justice particularly through international agreements.

(Council of EKD 2009:10)

It then makes ten concrete proposals for what has to be done in reaction to the crisis. Those proposals all follow what the document describes as a leading guideline and what it calls a 'sustainable social market economy':

A global system based on this concept must have as its goals:

- an economy that benefits people without destroying the means of livelihood of future generations

- a (global) society that regards improving the situation of its poorest and most vulnerable members as its prime responsibility and

- a financial system that is subordinated to this responsibility.

And it then explains the logic behind such a sustainable social market economy:

Now of all times, there is a risk of relapsing into a way of thinking that considers economic good-sense, social justice and ecological responsibility to be antagonistic. A social market economy widened by sustainability factors may prevent the achievements of an ecologically oriented conversion from being abandoned again, and social justice being increasingly compromised by greater inequality

(Council of EKD 2009:12)

The statement ends with another prophetic text. The famous passage from Isaiah 58:7-12 about the sharing of the bread with the hungry and bringing the homeless poor into one's house and the light which shall break forth like the dawn, makes clear that justice for the poor is no sacrifice for the privileged, but means a healing which ultimately fosters the well being of the rich as well.

The attention this church document received was astonishing. The EKD-Council President Wolfgang Huber presented it with a speech in Berlin. Among the listeners were the President of Germany, Horst Köhler and his wife, German Chancellor Angela Merkel, Foreign Minister Frank-Walter Steinmeier, other cabinet ministers, the chairmen and general secretaries of the big German parties. They all listened to the highest representative of the Protestant churches in Germany and heard a clear message. It is hard to measure what effect such an event and the whole document has had. But there is reason to believe that the widespread positive reaction also expressed a readiness to think about the messages in the document. In addition, it was remarkable that Franz Segbers, who had started the signature campaign against the previous EKD document together with Ulrich Duchrow, now highly praised the new document on the economic crisis (Segbers 2009).

We have an example here for the constructive potential of prophetic witness in European societies. In a situation in which the church is rooted in the midst of society, which also means being rooted among people with different political views, this document has used prophetic speech to criticise old and encourage new thinking. German Catholic Cardinal Karl Lehmann has once said about a former critical document by the churches that it had been 'fatally praised' ('totgelobt'). The danger that everybody embraces a critical document until its critical impulse is gone indeed has to be considered. But the chances can equally be emphasised. If different parties and organisations 
praise a church document, such appraisal is the best basis for the church's critical assessment of their concrete political actions.

Which systematic conclusions can now be drawn from the reflection on the concrete cases I have presented from the context of German society?

I will propose ten such conclusions.

\section{TEN SYSTEMATIC CONCLUSIONS}

1. Prophetic speech is a vital form of witness of the church also in politics. As German Old Testament scholar Hans-Joachim Kraus puts it, prophets, in the midst of our existing reality, claim the greater, more comprehensive reality of God and thereby, simply through the word either of judgment or of promise, turn this empirical reality with its laws and principles, upside down (Kraus 1986:19). Thus, prophetic witness can never be neutral or simply in a moderating position. Prophetic speech is characterised by the passion for justice. Its goal must be the actual improvement of the situation of the most disadvantaged. The idea of the 'preferential option for the poor' which has emerged as a concept originally from Latin American Liberation theology in the 1970s (Boff \& Pixley 1987) has a firm base in scripture (Bedford-Strohm 1993), especially in prophetic texts (Segbers 2002) and has meanwhile become the basis for church statements on the economy in many parts of the world and ecumenical social thought in general (Gabriel \& Gassner 2007).

2. Prophetic speech in a biblical perspective is 'connected criticism' (Walzer 1993). It is based on relationship, on love and respect for those to whom it is addressed. The addressees usually sense very well whether the critical passion of a prophetic voice is generated by love for people or whether it is generated by disgust for people. Only the former can claim to be a prophetic voice in the biblical sense.

3. Prophetic speech must therefore always happen in the context of reflection upon its consequences for the potential of political change in favour of the poor and disadvantaged. Discerning the spirits is a crucial task in reflecting upon prophetic witness. German theologian and church official Hermann Barth has suggested that the call to the churches to speak prophetically is often not primarily motivated by Old Testament prophetism but serves as a chiffre for clearcut criticism of society, resistance or confrontation with the governing powers (Barth 1999:257). Radical statements today do not automatically qualify as prophetic witness in the biblical sense. The self-perception of being the voice of God's truth is not sufficient. Claiming the authority of biblical prophecy for statements today is always in the danger of serving as a strategy of immunisation against critical objections.

4. The use of prophetic speech by the churches in public discourse has to be carefully considered and weighed against an alternative approach more oriented to the wisdom tradition. And yet, there is a clear place for it. Hermann Barth (1999:270-271) gives four criteria for the appropriateness of the prophetic approach in public statements of the church today. First, it must be a situation of exceptional importance with much at stake, only fully honored by a strong prophetic statement. Secondly, there must be an apparent necessity to appeal to people's conscience. Action or non-action must be a matter which touches the very identity of people's lives. Thirdly, there must be a situation in which there is no longer time for extended discussion and descriptions of the situation, rather than immediate repentance and fourthly it must be a time for truth without compromise. Beyond comfortable and sometimes necessary compromises there can and must be a time for simple truth telling. Such truth telling is ultimately in the best interest of those who bear the burden of political responsibility. These four criteria can help discern when and to what extent a public statement by the church or one of its representatives is guided by a prophetic approach.

5. Prophetic voices need not always be constructive. Their primary task is to call for repentance and change of mind and attitude. They can passionately criticise injustice without already knowing a clear workable path towards justice. Yet they cannot be put against the wisdom-oriented approach. Deconstructive prophetic voices cannot claim any moral prevalence against those approaches which work towards justice in little steps in the daily political process. There is a time for both, and both can even be elements of the same single statement.

6. Prophecy has a special role in dictatorships in which fundamental criticism, delegitimising the system, is the most appropriate mode of achieving change. In democratic societies prophetic speech must be related to the 'ecology of consciousness' of a dynamic civil society. If prophetic speech can help to change basic attitudes, it is ethically requested. If it blocks changes of mind in the public realm, it can even be ethically questionable.

7. Liberation theology had to give a special place to prophetic speech as a critique of power, because it was developed in a situation of dictatorship and oppression. Nico Koopman (2009) has described how prophetic speech in the apartheid society of South Africa entailed fearless criticism and resistance. In post-apartheid South Africa, however, he sees 'prophetic envisioning and indictment ... to a higher extent coupled with technical analysis of the political, economic, social, cultural and even religious forces of society' and he quotes African-American theologian Cornel West as a witness in his plea for going beyond pure criticism of power and for working out practical improvements for the oppressed in their everyday lives (Koopman 2009:7879). While Koopman sees this as part of the prophetic task, one could also conclude that this strongly discursive mode of public involvement means going beyond a purely prophetic approach and integrating it into an approach which Koopman himself and many others call the "public theological' approach.

8. Such public theology can be seen as a form of liberation theology for a civil society. In democratic societies, political offices depend on elections and therefore on a dynamic opinion building process in the public realm. Public theology, having grown into a worldwide theological paradigm (Storrar \& Morton 2004), has been developed to a considerable extent in South Africa, mostly in the postapartheid era (de Gruchy 2004; for the most comprehensive account see Smit 2007). The context of South Africa, moving from a society suppressing free speech into a civil society in which a public discourse with the participation of religious communities is needed and wanted, implies new challenges for the theological existence of the churches. Churches must make themselves understandable in the discourse. The moral positions of Christians must be accessible also to nonChristians (Koopman 2009:80; De Villiers 1999). Therefore, public theology must be bilingual - speaking both a theological and a secular language (Bedford-Strohm 2007).

9. In a democratic public with many voices, but unequal possibilities of getting public attention, prophetic action, creative forms of protest and civil disobedience in morally crucial situations have an important function. But they must be related to free discourse and the exchange of arguments about the best way to achieve moral goals. If prophetic witness blocks such exchange of arguments, it is an obstacle for change.

10. The churches have a special function as agents in civil society. They know about the undisputable moral truths on which a society depends, such as the dignity of every 
human being and the preference for the poor for which the biblical prophets stand. At the same time, they see the world as a whole reconciled by God in Jesus Christ and therefore stand for the inclusion of each member of society into a commonwealth based on those moral truths. Their mode of action in democratic societies is therefore an 'inclusive prophetism' based on biblical truths and supported by good arguments in the public discourse.

\section{CONCLUSION}

Prophetic witness can be in tension with the discourse of modern publics. Used in the right time and at the right place, however, prophetic witness can be a vital source of guidance for public discourse and therefore a powerful resource for the whole of society.

\section{REFERENCES}

Barth, H., 1999, Prophetie und Weisheit in kirchlichen Äußerungen [Prophesy and Wisdom in church statements], in I. Baldermann, E. Dassmann, O. Fuchs, B. Hamm, O. Hofius, B. Janowski et al. (Hrsg.), Prophetie und charisma, Jahrbuch für Biblische Theologie 14, pp. 257-274, Neukirchener Verlag, Neukirchen-Vluyn.

Bedford-Strohm, H., 1993, Vorrang für die Armen: Auf dem Wege zu einer theologischen Theorie der Gerechtigkeit, [Preference for the poor: Towards a theological theory of justice] Gütersloher Verlag, Gütersloh.

Bedford-Strohm, H., 2007, 'Nurturing reason: The public role of religion in the liberal state', Nederduits Gereformeerde Theologiese Tydskrif 48, 25-41.

Bedford-Strohm, H., 2008, 'Poverty and Public Theology: Advocacy of the Church in Pluralistic Society', International Journal of Public Theology 2, 144-162.

Boesak, A., 2009, 'Theological reflections on Empire', in A. Boesak \& L. Hansen (eds.), Globalisation: The politics of empire, justice and the life of faith, pp. 59-72, African Sun Media, Stellenbosch.

Boff, C. \& Pixley, J., 1987, Die Option für die Armen [Option for the poor], Patmos, Düsseldorf.

Council of the EKD, 2006, 'Just participation: Empowerment for personal Responsibility', A memorandum of the Council of the Evangelical Church in Germany on poverty in Germany, viewed 18 January 2010, from http://www.ekd.de/english/ download/gerechte_teilhabe_englisch.pdf

Council of the $E K D, 2009$, 'Like a high wall, cracked and bulging', Statement by the Council of the Evangelical Church in Germany on the global financial and economic crisis, viewed 18 January 2010, from http://www.ekd.de/english/ekd_texte_100.html

De Gruchy, J., 2004, 'From political to public theologies: The role of theology in public life in South Africa', in W.F. Storrar \& A.R. Morton (eds.), Public theology for the 21st century: Essays in honour of Duncan Forrester, pp. 45-62, T\&T Clark, London, New York.
De Villiers, E., 1999, 'Challenges to Christian ethics in the present South African society', Scriptura 69, 75-91.

Duchrow, U. \& Segbers, F. (Hrsg.), 2008, Frieden mit dem Kapital? Wider die Anpassung der evangelischen Kirche an die Macht der Wirtschaft. Beiträge zur Kritik der Unternehmerdenkschrift der EKD [Peace with the capital? Against the adaptation of the Protestant Church to the power of business: Contributions to the critique of the EKD business ethics memorandum], PublikForum-Verlagsgesellschaft, Oberursel.

Gabriel, I. \& Gassner, F. (Hrsg.), 2007, Solidarität und Gerechtigkeit: Ökumenische Perspektiven [Solidarity and justice: ecumenical perspectives], Mathias Grünewald Verlag, Mainz.

Kant, I., 1911, Grundlegung zur Metaphysik der Sitten [Groundwork of the metaphysics of morals], Akademie-Ausgabe, vol. IV, Reimer-Verlag, Berlin.

Koopman, N., 2009, 'Religion, public life and public policy in South Africa, in C. Le Bruyns \& G. Ulshöfer (eds.), The humanization of globalization: South African and German perspectives, pp. 73-86, Haag und Herchen Verlag, Frankfurt am Main.

Kraus, H.-J., 1986, Prophetie heute: Die Aktualität biblischer Prophetie in der Verkündigung der Kirche [Prophecy today: The timeliness of biblical prophecy in the preaching of the Church], Neukirchener Verlag, Neukirchen Vluyn

Luther, M., 2003, On Christian Liberty, Fortress Press, Minneapolis.

Rat der EKD, 2008, Unternehmerisches Handeln in evangelischer Perspektive, Hannover, [Entrepreneurial action in Protestant perspective]', Gütersloher Verlagshaus, Gütersloh.

Reihs, S., 2009, Zur Rezeption der EKD-Denkschrift »Unternehmerisches Handeln in evangelischer Perspektive«, [About the Reception of the EKD Memorandum Entrepreneurial Action in Protestant Perspective]', in $\mathrm{H}$. Bedford-Strohm, T. Jähnichen, H.R. Reuter, S. Reihs \& G. Wegner (Hrsg.), Jahrbuch Sozialer Protestantismus 3, pp. 207 221, Gütersloher Verlagshaus, Gütersloh.

Segbers, F., 2002, Die Hausordnung der Tora: Biblische Impulse für eine theologische Wirtschaftsethik [The house rules of the Tora: Biblical impulses for a theological economic ethicl, 3. Aufl., Edition Exodus, Luzern

Segbers, F., 2009,' Frische Brise in der Krise [A fresh breeze in the crisis]', Publik Forum 15, 14-15.

Smit, D., 2007, Essays in Public Theology: Collected essays 1, Study guides in religion and theology 12, ed. E.M. Conradie, Publications of the Western Cape, Stellenbosch. Stellenbosch.

Storrar, W.S. \& Morton, A. (eds.), 2004, Public Theology for the 21st Century, Essays in Honour of Duncan Forrester, T\&T Clark, London, New York.

Walzer, M., 1993, Interpretation and Social Criticism, Harvard University Press, Cambridge. 